\title{
Estimation of Wind Energy Potential for Two Locations in North-East Region of Nigeria
}

\author{
Abdullahi Ahmed*, Bashir Isyaku Kunya \\ Department of Mechanical Engineering, Kano University of Science and Technology, Wudil, Nigeria \\ Email address: \\ abdula2k2@yahoo.com (A. Ahmed) \\ ${ }^{*}$ Corresponding author \\ To cite this article: \\ Abdullahi Ahmed, Bashir Isyaku Kunya. Estimation of Wind Energy Potential for Two Locations in North-East Region of Nigeria. Journal \\ of Energy and Natural Resources. Vol. 9, No. 2, 2020, pp. 81-87. doi: 10.11648/j.jenr.20200902.15
}

Received: February 29, 2020; Accepted: March 26, 2020; Published: July 13, 2020

\begin{abstract}
This paper presents an estimation of wind power potential of North East, Nigeria (Bauchi and Maiduguri) on the basis of monthly wind speed data at $10 \mathrm{~m}$ height from the ground. The data for the locations were collected from Nigeria metrological station, Abuja for the period of (2013-2017). Mean monthly values were used in calculation of Weibull distribution parameters $\mathrm{c}$ (scale factor $\mathrm{ms}^{-1}$ ) and $\mathrm{k}$ (shape factor). The Weibull results shows that for Bauchi, the shape factor ranges from $2.86-5.96$ and scale factor ranges from $2.32 \mathrm{~ms}^{-1}-2.54 \mathrm{~ms}^{-1}$ while Maiduguri the shape factor ranges from $2.66-$ 5.52 and values of scale factor ranges from $4.74 \mathrm{~ms}^{-1}-5.89 \mathrm{~ms}^{-1}$. It is evident that the maximum average monthly value of wind speed in Bauchi occurs in year 2017 with value of $3.8 \mathrm{~ms}^{-1}$ in the month of May while the maximum average wind speed in Maiduguri occurs in year 2013 with value of $8.5 \mathrm{~ms}^{-1}$ in the month of December. The probability distribution function $\mathrm{f}(\mathrm{V})$ of wind speed, together with the duration function $T(V)$ was evaluated for the period under investigation. From the statistical analysis of distributions, the Weibull distribution was found to have better fittings in the probability distribution functions $\mathrm{f}(\mathrm{V})$ and $\mathrm{T}(\mathrm{V})$. The value of power density was computed to be $33.47 \mathrm{~W} / \mathrm{m}^{2}$ (class I) \& $374.62 \mathrm{~W} / \mathrm{m}^{2}$ (class II) and energy density was also computed to be $24.9 \mathrm{kWh} / \mathrm{m}^{2} \& 278 \mathrm{kWh} / \mathrm{m}^{2}$ for both Bauchi and Maiduguri respectively.
\end{abstract}

Keywords: Weibull Distribution, Weibull Parameters, Duration Function, Wind Energy

\section{Introduction}

Wind energy is the energy that is extracted from the wind using mechanical turbines. Even though it is a renewable energy resource. The contribution of wind energy varies between different years. Hence an efficient power management technique is followed to harvest maximum energy when there is excess wind and it can be used to compensate when wind mill production is low. Wind energy can be harnessed for grid and non-grid electricity generation, water pumping, irrigation and milling [1].

Wind energy is currently the most economic renewable energy apart from hydropower. Its usage versatility and ability to use it as a decentralized energy form make its application possible in rural areas where it is technically and economically feasible in the country. The major challenge to using wind as a source of electricity generation is that wind is intermittent and does not always blow when electricity is needed [3].

The wind systems that exist over the earth's surface are as result of variation in the pressure. These are due to the variations in solar heating, warm air rises and cooler air rushes in to take its place. Wind is merely the movement of air from one place to another due to uneven heating of the earth's atmosphere which causes temperature difference between land and seas, or mountain and valleys [5].

Wind speed generally increase with height above the ground, this is due to roughness of ground features such as vegetation and house which results to slowing down the wind speed.

Wind energy has been used since earliest civilization to grind grain, pump water from deep wells and power sail boat. Wind mills in Europe pre-industrial were used for many applications. The utilization of wind energy has been increasing around the world at an accelerating pace [7]. However, the development of new wind projects continues to be hampered by lack of reliable and accurate wind resource data in many parts of the world. Such data are needed to enable governments, private developers and others to determine the priority that should be given to wind energy 
utilization and to identify potential areas that might be suitable for development. The distribution of wind speeds is important for the design of wind farms, power generators and agricultural applications; such as irrigation [2].

These sources of energy are inexhaustible, clean and free. They offer many environmental and economic benefits in contrast to conventional energy sources. Wind energy is considered as a cost effective energy and its technological advancements allow it to compete with conventional power generation technologies [3].

Today, wind analysis provides remarkable information to researchers and designers that are involved in renewable energy studies, a large number of studies have been published amongst which are: Akpinar [1] presented a work on statistical analysis of wind energy potential on the basis of the Weibull and Rayleigh distribution for Agin-Elazig, Turkey. The work studies 5 years measured wind speed data based on the Weibull and Rayleigh models. The Weibull distribution provides better power density estimation in all twelve months than the Rayleigh models. Emami [4] worked on the statistical evaluation of wind speed and power density in the Firouzkouh region in Iran. The work studies an hourly average wind data which was observed for one year (2003) at Firouzkouh meteorological station, from his result he found that the region is quite favorable for wind power generation.

Wind Speed Data and Sites Description

The present study was based on data source measured at a height of $10 \mathrm{~m}$ above the ground level for Bauchi and Maiduguri North East, Nigeria. The wind speed data was collected from Nigerian meteorological station NIMET, Abuja for the period of (2013 - 2017). The geographical locations of Bauchi and Maiduguri North East, Nigeria are presented in Table 1 below. The locations have vegetation zone classified as Sudan zone and blessed with abundant vast land for agricultural activities.

However, the main objective of this present study is to estimate the wind energy potential for North-East region of Nigeria (Bauchi and Maiduguri) because the demand of power is increasing due to increase in human activities. It has been forecast that the present source of energy which if fossil fuel will gradually be depicted, hence the use wind energy for this locations have been found quite promising as an alternative energy source.

Table 1. Geographical data for the selected location.

\begin{tabular}{|c|c|c|c|c|c|}
\hline Locations & State & Lat (N) & Long (E) & Alt (m) & Alt (ft) \\
\hline Bauchi & Bauchi & $10^{\circ} 18^{\prime} 57$ & $9^{\circ} 5039$ & 615 & 2020 \\
\hline Maiduguri & Borno & $11^{\circ} 50^{\prime}, 47$ & $13^{\circ} 9^{\prime} 37$ & 299 & 984 \\
\hline
\end{tabular}

Source: http://www.fallingrain.com

\section{Available Power and Extractable Power of the Wind}

The power in wind is equal to energy per unit time. The energy available is the kinetic energy of the wind which is equal to the volume of air passing through an area $(A)$ with wind speed in time $(t)$. The power and energy density equation can be expressed as shown below [6];

Power density;

$$
\begin{gathered}
P=\frac{1}{2} \rho A V_{f}^{3} \\
\frac{P}{A}=\frac{1}{2} \rho V_{f}^{3}
\end{gathered}
$$

The actual power that can be extracted from wind depend on several factors, such as type of machine and rotor used, sophistication of blade design, friction losses, and losses in the machine or other equipment connected to the wind machine.

The possible extract maximum theoretical efficiency of a wind machine is $59.3 \%$ of the wind power, this is known as Betz limit.

The maximum power a wind machine can extract can be expressed in the equation below [12];

$$
\text { Maximum Power }=\frac{0.593}{2} * \rho * V^{3} * A
$$

In practice, a wind machine extracts substantially less power than this maximum. For example, the wind mill itself may capture only $70 \%$ of maximum power. Bearing will lose another few percentages to friction, generators, gears and other rotating machinery [8].

where; $P$ is power density (Watts), $A$ is area $\left(m^{2}\right), \rho$ is density and $V$ is velocity $(\mathrm{m} / \mathrm{s})$.

\section{Wind Speed Distribution}

In order to evaluate the wind energy potential of any site, it is important to derive the expected probability distribution of the site's wind speed. Weibull distribution parameter has been widely used in analysis of wind speed because it gives good match with the experimental data [11].

The wind speed probability distribution is essential in wind energy studies. The probability distribution could be used to evaluate the following [7];

The capacity factor for a particular wind turbine generator used in producing any form of energy

The probability for the wind speed to lie in a certain interval especially when the speed is above cut in speed of the turbine.

The mean wind power density.

The probability density function for the wind velocity $v(\mathrm{~m} / \mathrm{s})$ is given by $[9,14]$;

$$
f_{w}(v)=\left(\frac{k}{c}\right)\left(\frac{v}{c}\right)^{k-1} \exp \left[-\left(\frac{v}{c}\right)^{k}\right]
$$




$$
\begin{gathered}
F_{w}(v)=1-\exp (v / c)^{k} \\
T(v)=8760 \text { exp }\left[-\left(\frac{v}{c}\right)^{k}\right] \\
f(v)=\left(\frac{k}{c}\right)\left(\frac{v}{c}\right)^{k-1} \exp \left[-\left(\frac{v}{c}\right)^{k}\right]
\end{gathered}
$$

The Weibull parameters (scale and shape factors) can be calculated analytically from the available wind speed data using the relations below $[10,13]$;

$$
\begin{gathered}
c=v_{m}\left[\frac{k^{2.6674}}{0.184+\left(0.816 k^{2.73859}\right)}\right] \\
k=\left[\frac{\sigma}{v}\right]^{-1.090}
\end{gathered}
$$

where; $f_{W}$ is Weibull probability density function, $F_{W}$ is the Weibull cumulative distribution function, $T(V)$ is frequency distribution duration function, $c$ is the scale factor $(\mathrm{m} / \mathrm{s})$ and $k$ is the shape factor (dimensionless). $A=\pi r^{2}$

\section{Results and Discussion}

In this study, the wind speed data were recorded for two locations in North East (Bauchi and Maiduguri) for the period of (2013-2017) which have been statistically analyzed. The wind speed data of the two sites were obtained from Nigeria metrological station, Abuja. Based on these data, the wind speeds were analyzed and processed using spreadsheet and Wind Information System (WIS) software. The main results obtained are summarized as follows:

\section{Wind Characteristics and Weibull Parameters}

The average yearly wind speed values $V_{m}$ and Weibull parameters $k$ and $c$ are presented in Table 2 and Table 8 for both locations for the period of $(2013-2017)$. It can be seen from Table 2 that, the average wind speed values are between $2.07-2.31 \mathrm{~ms}^{-1}$ for Bauchi while for Table 8, the values ranges from $4.30-5.27 \mathrm{~ms}^{-1}$ for Maiduguri.

Similarly, values of the two Weibull parameters, the scale factor $\left(\mathrm{ms}^{-1}\right)$ and shape factor (dimensionless), calculated from the long term wind data for the sites studied with values of (shape factor) ranges from 2.86 - 5.96 and values of (scale factor) ranges from $2.32 \mathrm{~ms}^{-1}-2.54 \mathrm{~ms}^{-1}$ for Bauchi, while

\begin{tabular}{|c|c|c|c|c|c|}
\hline Year & 2013 & 2014 & 2015 & 2016 & 2017 \\
\hline Average wind speed $\left(V_{\mathrm{m}}\right)$ & 2.28 & 2.25 & 2.30 & 2.31 & 2.07 \\
\hline Shape factor (k) & 5.96 & 4.17 & 3.94 & 4.42 & 2.86 \\
\hline Scale factor (c) & 2.46 & 2.48 & 2.54 & 2.54 & 2.32 \\
\hline
\end{tabular}
values of (shape factor) ranges from $2.66-5.52$ and values of (scale factor) ranges from $4.74 \mathrm{~ms}^{-1}-5.89 \mathrm{~ms}^{-1}$ for Maiduguri.

Table 2. Values Obtained for Mean Yearly Wind Speed, Shape and Scale Factors for Bauchi.

It can be seen from Tables 3 - 7 below, that the values of power and energy density increases with increase in the monthly average wind speed, while the duration function $T(V)$ decreases with increase in wind speed. It is evident from the wind speed data, that the maximum average monthly value of wind speed in Bauchi from year (2013 -2017) occurs in year 2017 with value of $3.8 \mathrm{~ms}^{-1}$ in the month of May. The highest power and energy density were obtained in year 2017 in the month of May with values of $33.47 \mathrm{~W} / \mathrm{m}^{2}$ and $24.90 \mathrm{kWh} / \mathrm{m}^{2}$ respectively, while the lowest power and energy density occurred in year 2015 with values $101.49 \mathrm{~W} / \mathrm{m}^{2}$ and $755.08 \mathrm{kWh} / \mathrm{m}^{2}$ respectively. From the Weibull probability distribution function, it is noticeable that the highest probability density function $F(V)$ occurred in year 2016 in the month of August with value of 0.6509 and the lowest occurred in year 2013 in month of June with value of 0.0009 . For the duration function $T(V)$, the highest value

\begin{tabular}{|c|c|c|c|c|c|}
\hline Months & Wind speed $(\mathrm{m} / \mathrm{s})$ & Power density $\left(\mathrm{W} / \mathrm{m}^{2}\right)$ & Energy density $\left(\mathrm{kWh} / \mathrm{m}^{2}\right)$ & $\mathbf{F}(\mathbf{V})$ & $\mathbf{T}(\mathbf{V})$ \\
\hline Jan & 2.3 & 7.42 & 5.52 & 0.011 & 4461.54 \\
\hline Feb & 1.7 & 3.00 & 2.01 & 0.004 & 7836.66 \\
\hline Mar & 2.0 & 4.88 & 3.63 & 0.008 & 6532.75 \\
\hline Apr & 2.4 & 8.43 & 6.07 & 0.011 & 3671.96 \\
\hline May & 2.8 & 13.39 & 9.96 & 0.007 & 991.57 \\
\hline Jun & 3.2 & 19.99 & 14.39 & 0.001 & 70.104 \\
\hline Jul & 2.7 & 12.01 & 8.93 & 0.008 & 1515.92 \\
\hline Aug & 2.3 & 7.42 & 5.52 & 0.011 & 4461.54 \\
\hline Sep & 2.2 & 6.50 & 4.64 & 0.010 & 5220.03 \\
\hline Oct & 1.8 & 3.56 & 2.65 & 0.006 & 7490.33 \\
\hline Nov & 1.9 & 4.18 & 3.01 & 0.007 & 7057.49 \\
\hline Dec & 2.1 & 5.65 & 4.20 & 0.008 & 5917.06 \\
\hline
\end{tabular}
occurs in year 2016, in the month of December with value of 8444.45 while the lowest value occurs in year 2013 month of June with value of 70.10 .

Table 3. Bauchi power and energy density wind speed for year 2013. 
Table 4. Bauchi power and energy density wind speed for year 2014.

\begin{tabular}{|c|c|c|c|c|c|}
\hline Months & Wind speed $(\mathrm{m} / \mathrm{s})$ & Power density $\left(\mathrm{W} / \mathrm{m}^{2}\right)$ & Energy density $\left(\mathrm{kWh} / \mathrm{m}^{2}\right)$ & $F(V)$ & $\mathbf{T}(\mathbf{V})$ \\
\hline Jan & 2.4 & 8.43 & 6.27 & 0.6339 & 3662.24 \\
\hline Feb & 1.9 & 4.18 & 2.92 & 0.5200 & 6304.04 \\
\hline Mar & 1.6 & 2.50 & 1.86 & 0.3567 & 7460.25 \\
\hline Apr & 2.4 & 8.43 & 6.07 & 0.6339 & 3662.24 \\
\hline May & 2.9 & 14.88 & 11.07 & 0.4048 & 1282.96 \\
\hline Jun & 2.5 & 9.53 & 6.86 & 0.6137 & 3114.63 \\
\hline Jul & 3.0 & 16.47 & 12.25 & 0.3367 & 958.15 \\
\hline Aug & 2.6 & 10.72 & 7.98 & 0.5783 & 2591.48 \\
\hline Sep & 2.9 & 14.88 & 10.71 & 0.6383 & 1282.96 \\
\hline Oct & 2.2 & 6.50 & 4.83 & 0.6273 & 4776.06 \\
\hline Nov & 1.4 & 1.67 & 1.21 & 0.2501 & 7990.07 \\
\hline Dec & 1.2 & 1.05 & 0.78 & 0.1602 & 8346.52 \\
\hline
\end{tabular}

Table 5. Bauchi power and energy density wind speed for year 2015.

\begin{tabular}{|c|c|c|c|c|c|}
\hline Months & Wind speed $(\mathrm{m} / \mathrm{s})$ & Power density $\left(\mathrm{W} / \mathrm{m}^{2}\right)$ & Energy density $\left(\mathrm{kWh} / \mathrm{m}^{2}\right)$ & $\mathbf{F}(\mathbf{V})$ & $\mathbf{T}(\mathbf{V})$ \\
\hline Jan & 2.7 & 12.01 & 8.93 & 0.5207 & 2469.63 \\
\hline Feb & 1.8 & 3.56 & 2.38 & 0.4341 & 6778.89 \\
\hline Mar & 1.4 & 1.67 & 1.25 & 0.2437 & 7963.90 \\
\hline Apr & 2.6 & 10.72 & 7.72 & 0.5551 & 2941.62 \\
\hline May & 3.2 & 19.99 & 14.87 & 0.2568 & 739.24 \\
\hline Jun & 2.6 & 10.72 & 7.72 & 0.5551 & 2941.62 \\
\hline Jul & 2.9 & 14.88 & 11.07 & 0.4257 & 1636.39 \\
\hline Aug & 2.5 & 9.53 & 7.09 & 0.5783 & 3438.93 \\
\hline Sep & 2.8 & 13.39 & 9.64 & 0.4768 & 2023.10 \\
\hline Oct & 2.3 & 7.42 & 5.52 & 0.5881 & 4467.89 \\
\hline Nov & 1.7 & 3.00 & 2.16 & 0.3865 & 7138.47 \\
\hline Dec & 1.1 & 0.81 & 0.61 & 0.1272 & 8443.05 \\
\hline
\end{tabular}

Table 6. Bauchi power and energy density wind speed for year 2016.

\begin{tabular}{|c|c|c|c|c|c|}
\hline Months & Wind speed $(\mathrm{m} / \mathrm{s})$ & Power density $\left(\mathrm{W} / \mathrm{m}^{2}\right)$ & Energy density $\left(\mathrm{kWh} / \mathrm{m}^{2}\right)$ & $\mathbf{F}(\mathbf{V})$ & $T(V)$ \\
\hline Jan & 2.5 & 9.53 & 7.09 & 0.6483 & 3431.51 \\
\hline Feb & 2.1 & 5.65 & 3.93 & 0.5912 & 5675.52 \\
\hline Mar & 1.7 & 3.00 & 2.23 & 0.3738 & 7384.97 \\
\hline Apr & 2.7 & 12.01 & 8.65 & 0.5771 & 2348.49 \\
\hline May & 3.3 & 21.92 & 16.31 & 0.1754 & 359.68 \\
\hline Jun & 2.7 & 12.01 & 8.65 & 0.5771 & 2348.49 \\
\hline Jul & 2.6 & 10.72 & 7.98 & 0.6209 & 2874.33 \\
\hline Aug & 2.3 & 7.42 & 5.52 & 0.6509 & 4579.69 \\
\hline Sep & 2.8 & 13.39 & 9.64 & 0.5195 & 1867.29 \\
\hline Oct & 2.2 & 6.50 & 4.83 & 0.6277 & 5140.77 \\
\hline Nov & 1.6 & 2.50 & 1.80 & 0.3164 & 7687.11 \\
\hline Dec & 1.2 & 1.05 & 0.78 & 0.1301 & 8444.45 \\
\hline
\end{tabular}

Table 7. Bauchi power and energy density wind speed for year 2017.

\begin{tabular}{lllll}
\hline Months & Wind speed $(\mathbf{m} / \mathbf{s})$ & Power density $\left(\mathbf{W} / \mathbf{m}^{2}\right)$ & Energy density $\left(\mathbf{k W h} / \mathbf{m}^{2}\right)$ & F(V) \\
\hline Jan & 2 & 4.88 & 3.63 & 0.4853 \\
Feb & 2.4 & 8.43 & 5.67 & 0.4363 \\
Mar & 2.4 & 8.43 & 6.27 & 0.4363 \\
Apr & 3.0 & 16.47 & 11.86 & 0.2483 \\
May & 3.8 & 33.47 & 24.90 & 0.0520 \\
Jun & 2.9 & 14.88 & 10.71 & 0.2824 \\
Jul & 2.4 & 8.43 & 6.27 & 1099.92 \\
Aug & 1.9 & 4.18 & 3.11 & 148.32 \\
Sep & 1.9 & 4.18 & 3.01 & 1332.30 \\
Oct & 1.7 & 3.00 & 2926.58 & 0.4822 \\
Nov & 1.3 & 1.34 & 2.23 & 0.4822 \\
Dec & 1.0 & 0.61 & 0.97 & 0.4570 \\
\end{tabular}


Table 8. Values Obtained for Mean Yearly Wind Speed, Shape and Scale Factors for Maiduguri.

\begin{tabular}{|c|c|c|c|c|c|}
\hline Year & 2013 & 2014 & 2015 & 2016 & 2017 \\
\hline Average wind speed $\left(V_{\mathrm{m}}\right)$ & 5.27 & 5.09 & 4.46 & 4.30 & 5.27 \\
\hline Shape factor $(\mathrm{k})$ & 3.34 & 4.25 & 2.66 & 4.11 & 5.52 \\
\hline Scale factor (c) & 5.89 & 5.60 & 5.02 & 4.74 & 5.71 \\
\hline
\end{tabular}

It can be seen from Tables $9-13$, that the values of power and energy density increases with increase in the monthly average wind speed, while the duration function $T(V)$ decreases with increase in wind speed. It is evident from the wind speed data, that the maximum average monthly value of wind speed in Maiduguri from year (2013 - 2017) occurs in year 2013 with value of $8.5 \mathrm{~m} / \mathrm{s}$ in the month of December. The highest power and energy density were obtained in year 2013 in the month of December with value of $374.62 \mathrm{~W} / \mathrm{m}^{2}$ and $278.72 \mathrm{kWh} / \mathrm{m}^{2}$ respectively, while the lowest power and energy density occurred in year 2013 and 2015 in the month of January and October with values of $6.50 \mathrm{~W} / \mathrm{m}^{2}$ and $4.83 \mathrm{kWh} / \mathrm{m}^{2}$ respectively. From the Weibull probability distribution function, it is noticeable that the highest probability density function $F(V)$ occurred in year 2017 in the month of March with value of 0.3380 and the lowest occurred in year 2013 in months of January with value of 0.0548 respectively. For the duration function $T(V)$, the highest value occurs in year 2013, in the month of January with value of 8437.95 while the lowest value occur in year 2014 month of February with value of 147.30 .

Table 9. Maiduguri power and energy density wind speed for year 2013.

\begin{tabular}{llllll}
\hline Months & Wind speed $(\mathbf{m} / \mathbf{s})$ & Power density $\left(\mathbf{W} / \mathbf{m}^{2}\right)$ & Energy density $\left(\mathbf{k W h} / \mathbf{m}^{2}\right)$ & $\mathbf{F}(\mathbf{V})$ & $\mathbf{T}(\mathbf{V})$ \\
\hline Jan & 2.1 & 6.50 & 4.83 & 0.0548 & 8437.95 \\
Feb & 3.1 & 18.17 & 13.52 & 0.1129 & 7786.19 \\
Mar & 5.6 & 107.13 & 79.70 & 0.2169 & 3742.28 \\
Apr & 5.9 & 125.28 & 90.20 & 0.2084 & 3182.39 \\
May & 6.2 & 145.38 & 108.16 & 0.1950 & 2651.36 \\
Jun & 6.9 & 200.39 & 144.28 & 0.1499 & 1586.34 \\
Jul & 6.7 & 183.47 & 136.50 & 0.1642 & 1861.57 \\
Aug & 4.9 & 71.77 & 53.39 & 0.2154 & 5082.87 \\
Sep & 4.3 & 48.50 & 34.92 & 0.1923 & 6162.15 \\
Oct & 4.3 & 48.50 & 36.08 & 0.1923 & 6162.15 \\
Nov & 4.6 & 59.37 & 42.75 & 0.2061 & 5637.77 \\
Dec & 8.5 & 374.62 & 278.75 & 0.0437 & 283.51 \\
\hline
\end{tabular}

Table 10. Maiduguri power and energy density wind speed for year 2014.

\begin{tabular}{llllll}
\hline Months & Wind speed $(\mathbf{m} / \mathbf{s})$ & Power density $\left(\mathbf{W} / \mathbf{m}^{2}\right)$ & Energy density $\left(\mathbf{k W h} / \mathbf{m}^{2}\right)$ & $\mathbf{F}(\mathbf{V})$ & $\mathbf{T}(\mathbf{V})$ \\
\hline Jan & 4.9 & 71.77 & 53.39 & 0.2789 & 4977.27 \\
Feb & 7.8 & 289.48 & 201.48 & 0.0375 & 147.30 \\
Mar & 6.2 & 145.38 & 108.16 & 0.2267 & 1880.98 \\
Apr & 5.8 & 119.02 & 85.69 & 0.2668 & 2750.62 \\
May & 4.3 & 48.50 & 36.08 & 0.2320 & 6333.77 \\
Jun & 6.1 & 138.46 & 99.69 & 0.2383 & 2084.69 \\
Jul & 6.3 & 152.53 & 113.48 & 0.2143 & 1687.79 \\
Aug & 4.3 & 48.50 & 36.08 & 0.2320 & 6333.77 \\
Sep & 4.0 & 39.04 & 28.11 & 0.1998 & 6901.83 \\
Oct & 3.9 & 36.19 & 26.92 & 0.1885 & 7071.92 \\
Nov & 3.2 & 19.99 & 14.39 & 0.1119 & 7987.94 \\
Dec & 4.3 & 48.50 & 36.08 & 0.2320 & 6333.77 \\
\hline
\end{tabular}

Table 11. Maiduguri power and energy density wind speed for year 2015.

\begin{tabular}{llllll}
\hline Months & Wind speed $(\mathbf{m} / \mathbf{s})$ & Power density $\left(\mathbf{W} / \mathbf{m}^{\mathbf{2}}\right)$ & Energy density $\left(\mathbf{k W h} / \mathbf{m}^{2}\right)$ & $\mathbf{F}(\mathbf{V})$ & $\mathbf{T}(\mathbf{V})$ \\
\hline Jan & 4.5 & 55.59 & 41.36 & 0.2095 & 4149.17 \\
Feb & 6.6 & 175.37 & 117.85 & 0.1053 & 1102.19 \\
Mar & 6.9 & 200.39 & 149.09 & 0.0874 & 849.34 \\
Apr & 5.7 & 112.97 & 81.34 & 0.1612 & 2154.33 \\
May & 5.9 & 125.28 & 93.21 & 0.1492 & 1882.33 \\
Jun & 5.8 & 119.02 & 85.69 & 0.1553 & 2015.69 \\
Jul & 5.3 & 90.81 & 67.57 & 0.1829 & 2758.35 \\
Aug & 3.5 & 26.15 & 19.46 & 0.1986 & 5975.11 \\
Sep & 2.3 & 7.42 & 5.34 & 0.1278 & 7730.47 \\
Oct & 2.2 & 6.5 & 4.83 & 0.1203 & 7839.16 \\
Nov & 2.7 & 12.01 & 8.65 & 0.1561 & 7232.23 \\
Dec & 2.1 & 5.65 & 4.20 & 0.1128 & 7941.30 \\
\hline
\end{tabular}


Table 12. Maiduguri power and energy density wind speed for year 2016.

\begin{tabular}{|c|c|c|c|c|c|}
\hline Months & Wind speed $(\mathrm{m} / \mathrm{s})$ & Power density $\left(\mathrm{W} / \mathrm{m}^{2}\right)$ & Energy density $\left(\mathrm{kWh} / \mathrm{m}^{2}\right)$ & $\mathbf{F}(\mathbf{V})$ & $\mathbf{T}(\mathbf{V})$ \\
\hline Jan & 2.5 & 9.53 & 7.09 & 0.1099 & 8153.16 \\
\hline Feb & 2.3 & 7.42 & 5.17 & 0.0866 & 8324.88 \\
\hline Mar & 3.0 & 16.47 & 12.25 & 0.1790 & 7524.10 \\
\hline May & 5.5 & 101.49 & 75.51 & 0.2187 & 1393.01 \\
\hline Jun & 4.5 & 55.59 & 40.02 & 0.3290 & 3914.63 \\
\hline Jul & 3.5 & 26.15 & 19.46 & 0.2528 & 6577.80 \\
\hline Sep & 4.8 & 67.46 & 48.57 & 0.3149 & 3064.34 \\
\hline Oct & 4.5 & 55.59 & 41.36 & 0.3290 & 3914.63 \\
\hline Nov & 5.1 & 80.92 & 58.26 & 0.2824 & 2275.87 \\
\hline Dec & 5.4 & 96.05 & 71.46 & 0.2361 & 1592.23 \\
\hline
\end{tabular}

Table 13. Maiduguri power and energy density wind speed for year 2017.

\begin{tabular}{|c|c|c|c|c|c|}
\hline Months & Wind speed $(\mathrm{m} / \mathrm{s})$ & Power density $\left(W / m^{2}\right)$ & Energy density $\left(\mathrm{kWh} / \mathrm{m}^{2}\right)$ & $F(V)$ & $T(V)$ \\
\hline Jan & 4.7 & 63.33 & 47.12 & 0.2857 & 6219.38 \\
\hline Feb & 5.0 & 76.25 & 51.24 & 0.3285 & 5409.99 \\
\hline Mar & 5.9 & 125.28 & 93.21 & 0.3380 & 2634.55 \\
\hline Apr & 6.1 & 138.46 & 99.69 & 0.3083 & 2066.84 \\
\hline May & 6.1 & 138.46 & 103.01 & 0.3083 & 2066.84 \\
\hline Jun & 6.8 & 191.80 & 138.10 & 0.1538 & 631.23 \\
\hline Aug & 4.9 & 71.77 & 53.39 & 0.3155 & 5692.20 \\
\hline Sep & 4.8 & 67.46 & 48.57 & 0.3011 & 5962.36 \\
\hline Oct & 3.5 & 26.15 & 19.46 & 0.0992 & 8189.75 \\
\hline Nov & 4.7 & 63.33 & 45.60 & 0.2856 & 6219.38 \\
\hline Dec & 3.8 & 33.47 & 24.90 & 0.1384 & 7879.14 \\
\hline
\end{tabular}

\section{Conclusion}

In this study, wind speed data for Bauchi and Maiduguri North East, Nigeria have been statistically analyzed. The Weibull probability distribution function have been derived from the wind speed data obtained from Nigeria metrological station, Abuja for the period of (2013-2017) and the probability function $F(V)$ and duration function $T(V)$ were evaluated.

It is quite evident that the wind energy in Maiduguri North East, Nigeria can provide up a maximum power and energy density of $374.62 \mathrm{~W} / \mathrm{m}^{2}$ and $278.72 \mathrm{kWh} / \mathrm{m}^{2}$ respectively, which is significant in generating electricity since the power density is above $100 \mathrm{~W} / \mathrm{m}^{2}$ which is classified as class I while for Bauchi the maximum power and energy density was obtained as $33.47 \mathrm{~W} / \mathrm{m}^{2}$ and $24.90 \mathrm{kWh} / \mathrm{m}^{2}$ which can be used for battery charging, water pumping and smaller electrical appliances since the power density is less than $100 \mathrm{~W} / \mathrm{m}^{2}$ which is classified as class II.

It can be concluded that the Weibull distribution is suitable to represent the actual probability of wind speed data for the North East region of Nigeria.

\section{Acknowledgements}

This research was funded by a grant from Tertiary Education Trust Fund (TETFUND) through "Institution Based Research" (IBR). Appreciation to the management of TETFUND and Federal Government of Nigeria $(F G N)$ for the financial support.

\section{References}

[1] E. K. Akinpar, S. Akinpar, "Determination of the wind energy potential for Maden, Turkey", Energy Conversion and Management, Vol. 45 (18) pp. 2901-2914 (2004).

[2] A. S. Ahmed, R. Shata Hanitsch, "Evaluation of wind energy potential and electricity generation on the coast of Mediterranean Sea Egypt", Renewable Energy, Vol. 31 (7) pp. 183-202 (2006).

[3] A. N Celik, "On the distributional parameters used in assessment of the suitability of wind speed probability density functions", Energy Conversion and Management, Vol. 45 (13) pp. 1735-1747 (2004).

[4] N. Emmani, H. Behbahani-Nia, "The statistical evaluation of wind speed and power density in the Firouzkouh region in Iran". Taylor and Francis, Vol. 34 (12) pp. 1076-1083 (2013).

[5] A. N. Celik, "A statistical analysis of wind power density based on the Weibull and Rayleigh Models at the southern region of Turkey". Renewable Energy, Vol. 29 (5) pp. 593-604 (2004).

[6] M. J. Stevens, P. T. Smulders, "The estimation of the parameters of the Weibull wind speed distribution for wind energy utilization purposes" Wind Engineering, Vol. 3 (2) pp. 132-84 (1979).

[7] S. A. Ahmed "Investigation of wind characteristics and wind energy potential at Ras Ghareb, Egypt" Renewable and Sustainable, Energy Reviews, Vol. 5 (2) pp. 2750-2755 (2003). 
[8] Z. Durisic, J. Mikulovic, "Assessment of the wind energy resource in the south Banat region Serbia", Renewable and Sustainable Energy Reviews, Vol. 16 (4) pp. 3014-3023 (2012).

[9] M. A Alsaad, "Wind energy potential in selected areas of Jordan", Energy Conversion and Management, Vol. 65 (10) pp. 704-708 (2013).

[10] J. O. Ojosu, R. I. Salawu, "A statistical analysis of wind energy potential for power generation in Nigeria", Solar and Wind Technology, Vol. 7 (2) pp. 155-167 (1990).

[11] K. Ulgen, A. Hepbasli, "Determination of Weibull parameter for wind energy analysis of Izmir, Turkey", International Journal of Energy Research, Vol. 26 (4) pp. 495-506 (2002).
[12] D. Watts, D. Jara, "Statistical analysis of wind energy in Chile", Renewable Energy, Vol. 36 (7) pp. 1603-1613 (2011).

[13] A. Ahmed "Estimation of wind energy potential for two locations in north west region of Nigeria", International Journal of Advanced Trends in Engineering, Science and Technology, Vol 1 (5) pp. 6-10 (2018).

[14] A. Ahmed "Investigation of wind energy resource on the basis of Weibull and Rayleigh models in north eastern and western Nigeria" American Journal of Aerospace Engineering, Vol 1 (6) pp. 27-32 (2019). 